B3

J. bio-sci. 14: 93-98, 2006

ISSN 1023-8654

\title{
SERUM LIPID PROFILE OF HYPERTENSIVE PATEINTS IN THE NORTHERN REGION OF BANGLADESH
}

\author{
M S Saha, N K Sana and Ranajit Kumar Shaha* \\ Department of Biochemistry \& Molecular Biology, \\ University of Rajshahi, Rajshahi 6205, Bangladesh
}

\begin{abstract}
A prospective study was conducted in the Northern region of Bangladesh, to investigate the serum lipid profile viz the level of total cholesterol (TC), Triglyceride (TG), HDL-cholesterol and LDL-cholesterol of hypertensive patients and compares them with levels of control subjects. The results revealed that serum total cholesterol, triglyceride and LDL-cholesterol were significantly markedly raised $(p<0.001)$ whereas the level of $\mathrm{HDL}$-cholesterol was significantly lower $(p<0.001)$ in hypertensive patients as compared to control subjects. No significant changes of serum lipid profile were found between male and female hypertensive patients, but in control subjects, markedly higher levels of serum lipid profile was observed in male compared to that of female. It was concluded that hypercholesterolaemia, hypertrigyceridaemia and low density lipoprotein are the main lipid abnormalities on the incidence of hypertension in the study area.
\end{abstract}

Keywords: Hypertension, Total cholesterol (TC), triglyceride (TG), HDL- cholesterol and LDL-cholesterol.

\section{Introduction}

Hypertension is the most common of the cardio-vascular diseases which is the leading cause of morbidity and mortality in the industrial world as well as becoming an increasing common disease in the developing countries (WHO, 1978). Hypertension in adults is arbitrarily defined as systolic pressure to or greater than $160 \mathrm{~mm} \mathrm{Hg}$ and or/ or diastolic pressure equal to or greater than $95 \mathrm{~mm} \mathrm{Hg}$ (WHO, 1978). Hypertension is one of the 10 leading reported causes of death and about $4 \%$ deaths were due to hypertensive complications (Bangladesh Health Services Report 1998). The prevalence of hypertension is higher among blacks than whites and it increases with age in all groups (Roberts and Mauer 1977). The most important risk factors for the development of hypertension are increased salt intake, obesity, cigarette smoking, elevated serum level, lack of physical exercise, genetic factors and stress and strain (Williams and Braunwald 1987). The blood lipids and lipoproteins are closely associated with hypertension. The serum lipid level of hypertensive patients is usually higher and can be lowered either by dietary restriction or by hypolipidemic agents (Lipid Research Clinics Program 1984 and Burke et al. 1991).

The changes in serum lipid profile level on hypertensive patients should be actively investigated. The findings of this study may help to understand the effect of renin-angiotensin system in the regulation of blood pressure. The aim and objectives of the present case-control study were to find out the relationship between serum lipids levels of the hypertensive patients with controls in the study area i.e. Northern Region of Bangladesh.

* To whom all correspondence should be addressed. 


\section{Materials and Methods}

This prospective study carried out from November 2001 to July 2002 in the Department of Biochemistry and Molecular Biology, University of Rajshahi, Rajshahi, Bangladesh. A total numbers of 60 human subjects of age ranging from 33-60 years were included in this study. Out of the 60 subjects, 20 normo-tensive volunteers ( 15 Males and 5 females) were selected as control (group1). The remaining 40 subjects ( 25 Males and 15 Females) were grouped as hypertensive (group 2). The body mss index (BMI) was calculated in all the subjects as it indicates the nutritional status. The study patients were randomly selected from the Coronary Care Unit (CCU) and the Department of Medicine, Rajshahi Medical College Hospital, Rajshahi.

Serum total cholesterol levels was determined by enzymatic (CHOD-PAP) colorimetric method (Allain et al. 1974) and triglyceride by enzymatic (GPO-PAP) method of (Jacobs and Van demark (1960). HDL-cholesterol and LDL-cholesterol were estimated using precipitant (Gordon and Gordon 1977) and Friedewald formula (Friedewald 1972). Above all parameters under investigation were determined in the serum of patients and controls using commercially available reagent kits. All values were expressed as mean \pm S.E. Statistical significance of differences between control and study groups were evaluated by student's " $t$ " test.

\section{Results}

In the present study, maximum numbers of patients of both sexes were between $50-60$ years of age and the percentage had declined sharply below these ages (Table 1).

Table 1. The age distribution of hypertensive patients.

\begin{tabular}{|c|c|c|c|}
\hline Sl. No. & Age Group (years) & Male (\%) & Female (\%) \\
\hline 1 & $<40$ & $3(7.5)$ & $2(5)$ \\
\hline 2 & $41-49$ & $7(17.5)$ & $5(12.5)$ \\
\hline 3 & $50-60$ & $15(37.5)$ & $8(20)$ \\
\hline Total & $\mathrm{n}=40$ & $25(62.5)$ & $15(37.5)$ \\
\hline
\end{tabular}

The mean serum total cholesterol levels were $182.14 \pm 4.45$ and $241.25 \pm 6.57 \mathrm{mg} / \mathrm{dl}$ and serum triglyceride levels were $142.73 \pm 6.68$ and $184.77 \pm 5.97 \mathrm{mg} / \mathrm{dl}$ in control and hypertensive patients respectively, which has been shown in Table 2 and Fig. 1. The results presented in Table 2 also demonstrated that the serum HDL- cholesterol and LDL-cholesterol levels in hypertensive patients were $32.91 \pm 1.21$ and $154.32 \pm 4.22$ $\mathrm{mg} / \mathrm{dl}$ and $42.88 \pm 0.93$ and $105.73 \pm 3.53 \mathrm{mg} / \mathrm{dl}$ respectively, in healthy volunteers.

Table 2. Serum lipid profile of group-I (healthy controls) and group-II (hypertensive patients).

\begin{tabular}{|l|c|c|c|c|}
\hline Group & $\begin{array}{c}\text { Total Cholesterol } \\
(\mathrm{mg} / \mathrm{dl})\end{array}$ & $\begin{array}{c}\text { Triglyceride } \\
(\mathrm{mg} / \mathrm{dl})\end{array}$ & $\begin{array}{c}\text { Serum HDL-cholesterol } \\
(\mathrm{mg} / \mathrm{dl})\end{array}$ & $\begin{array}{c}\text { LDL-cholesterol } \\
(\mathrm{mg} / \mathrm{dl})\end{array}$ \\
\hline $\begin{array}{l}\text { Group-I } \\
\mathrm{n}=20\end{array}$ & $182.14 \pm 4.45(110-245)$ & $142.73 \pm 6.68(85-210)$ & $42.88 \pm 0.93(40-56)$ & $105.73 \pm 3.53(70-165)$ \\
\hline $\begin{array}{l}\text { Group-II } \\
\mathrm{n}=40\end{array}$ & $241.25 \pm 6.57(180-310)$ & $184.77 \pm 5.97(140-240)$ & $32.91 \pm 1.21(32-52)$ & $154.32 \pm 4.22(110-230)$ \\
\cline { 2 - 5 } & $\mathrm{P}<0.001$ & $\mathrm{P}<0.001$ & $\mathrm{P}<0.001$ & $\mathrm{~S}$ \\
& $\mathrm{~S}$ & $\mathrm{~S}$ & $\mathrm{~S}$ & $\mathrm{~S}$ \\
\hline
\end{tabular}

Values are mean \pm standard error (S.E.), Figures in the parenthesis indicate range, $S=$ Significant. 


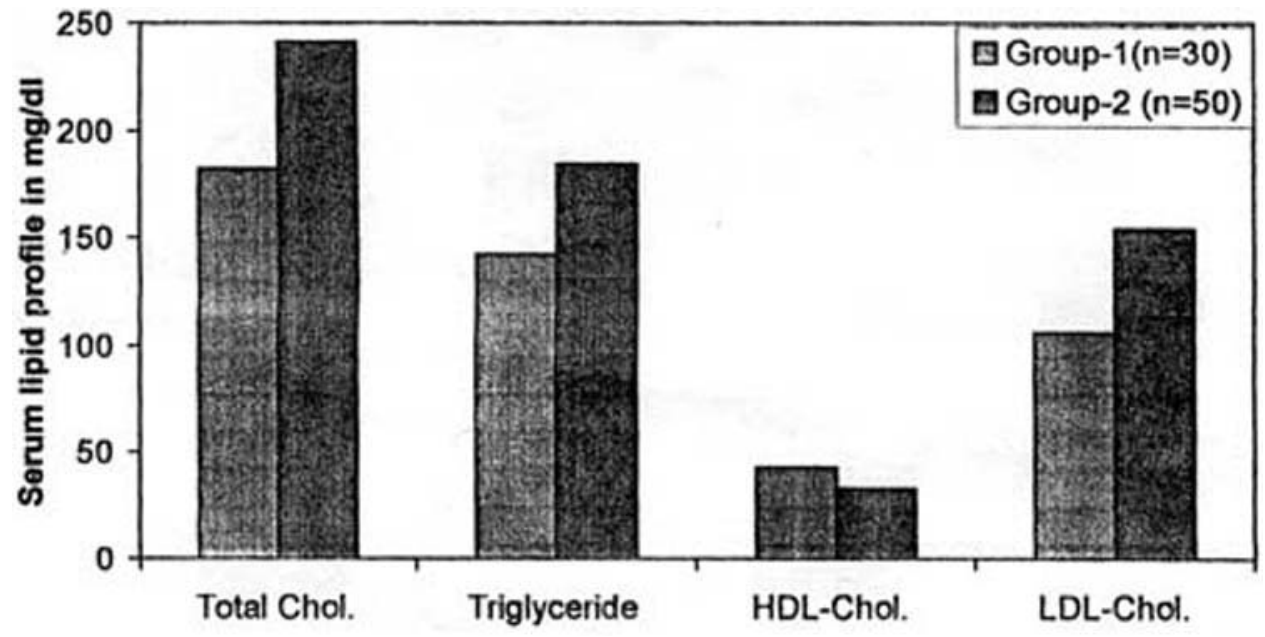

Fig. 1. Histogram showing the serum lipid profile of healthy controls (group 1) and hypertensive patients (group 2).

Among hypertensive patients, the differences of mean serum lipid level in male and female was not significant as shown in Table 3. On the other hand, significantly higher level of serum lipid was recorded in male compared to that of female of control patients (Table 4 and Fig. 2).

Table 3. Sex differences of serum lipid profile of group 2 (Hypertensive patients).

\begin{tabular}{|l|c|c|c|c|}
\hline \multicolumn{1}{|c|}{ Sex } & $\begin{array}{c}\text { Total Cholesterol } \\
(\mathrm{mg} / \mathrm{dl})\end{array}$ & $\begin{array}{c}\text { Triglyceride } \\
(\mathrm{mg} / \mathrm{dl})\end{array}$ & $\begin{array}{c}\text { Serum HDL-cholesterol } \\
(\mathrm{mg} / \mathrm{dl})\end{array}$ & $\begin{array}{c}\text { LDL-cholesterol } \\
(\mathrm{mg} / \mathrm{dl})\end{array}$ \\
\hline Male $\mathrm{n}=25$ & $242.18 \pm 6.78(190-310)$ & $181.53 \pm 5.03(152-240)$ & $31.18 \pm 1.12(36-52)$ & $154.50 \pm 5.15(117-230)$ \\
\hline Female $\mathrm{n}=15$ & $237.15 \pm 7.95(180-295)$ & $175.58 \pm 6.12(140-227)$ & $34.97 \pm 1.01(32-46)$ & $149.45 \pm 7.30(110-217)$ \\
\hline & $\mathrm{p}>0.6, \mathrm{~N} \mathrm{~S}$ & $\mathrm{p}>0.4, \mathrm{~N} \mathrm{~S}$ & $\mathrm{p}>0.1, \mathrm{~N} \mathrm{~S}$ & $\mathrm{p}>0.5, \mathrm{~N} \mathrm{~S}$ \\
\hline
\end{tabular}

Values are mean \pm standard error (S.E.), Figures in the parenthesis indicate range, N.S $=$ Not significant

Table 4. Sex differences of serum lipid profile of group 1 (Healthy control).

\begin{tabular}{|c|c|c|c|c|}
\hline Sex & $\begin{array}{c}\text { Total cholesterol } \\
(\mathrm{mg} / \mathrm{dl})\end{array}$ & $\begin{array}{c}\text { Triglyceride } \\
(\mathrm{mg} / \mathrm{dl})\end{array}$ & $\begin{array}{c}\text { Serum HDL- cholesterol } \\
(\mathrm{mg} / \mathrm{dl})\end{array}$ & $\begin{array}{c}\text { LDL-cholesterol } \\
(\mathrm{mg} / \mathrm{dl})\end{array}$ \\
\hline Male $\mathrm{n}=15$ & $193.12 \pm 5.28(130-245)$ & $157.25 \pm 8.14(105-210)$ & $39.51 \pm 0.98(44-58)$ & $112.45 \pm 4.69(85-165)$ \\
\hline Female $\mathrm{n}=5$ & $171 \pm 74.14(110-232)$ & $138.21 \pm 7.48(85-192)$ & $46.12 \pm 0.73(40-52)$ & $92.53 \pm 4.60(70-152)$ \\
\hline & $\mathrm{P}<0.02$ & $\mathrm{P}<0.01$ & $\mathrm{P}<0.05$ & $\mathrm{P}<0.05$ \\
$\mathrm{~S}$ & $\mathrm{~S}$ & $\mathrm{~S}$ & \\
\hline
\end{tabular}

Values are mean \pm standard error (S.E.), S= Significant. 


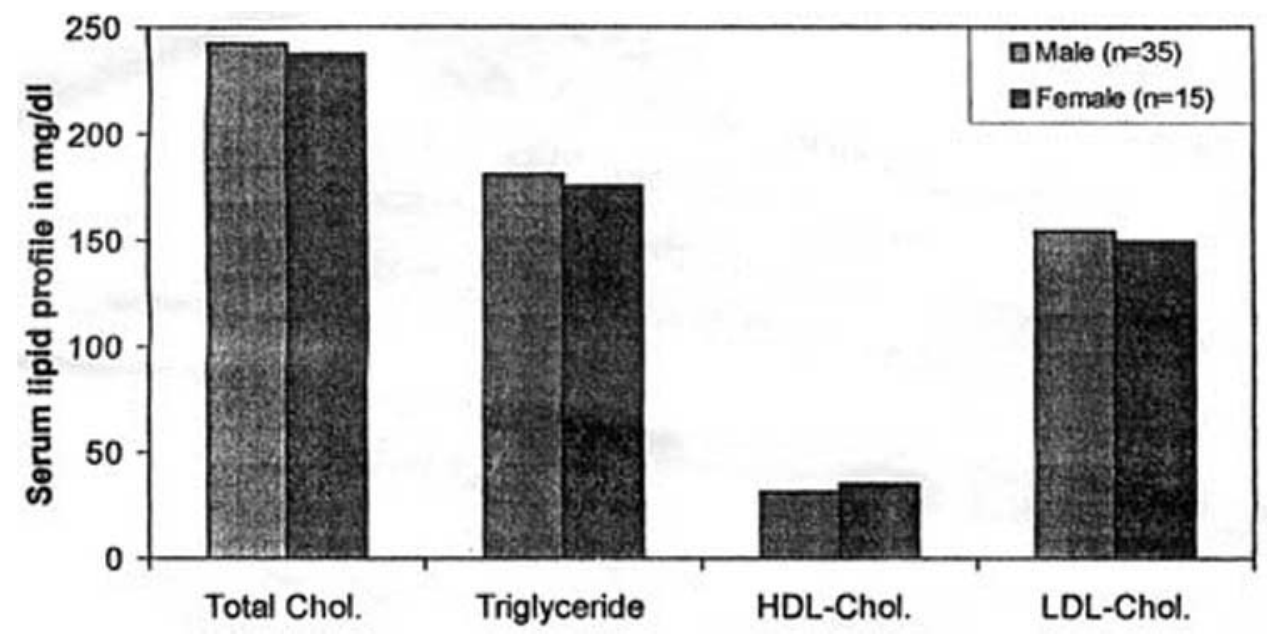

Fig 2. Histogram showing the sex differences of serum lipid profile of hypertensive patients (group 2).

Table 5. Characteristics of control and hypertensive patients.

\begin{tabular}{|l|l|l|}
\hline Characters & Group 1 $(\mathrm{n}=20)$ & Group 2 $(\mathrm{n}=40)$ \\
\hline Sex (Male and Female) & $(\mathrm{n}=20)$ & $(\mathrm{n}=40)$ \\
\hline Age $($ Years $)$ & $46.47 \pm 1.10(33-57)$ & $54.25 \pm 1.43(35-63)$ \\
\hline BMl & $21.53 \pm 0.26(19.05-24.65)$ & $22.01 \pm 0.2(20.01-24.80)$ \\
\hline Systolic BP $(\mathrm{mm} \mathrm{Hg})$ & $121.50 \pm 2.11(110-130)$ & $150.50 \pm 3.53(130-165)$ \\
\hline Diastolic BP $(\mathrm{mm} \mathrm{Hg})$ & $81.50 \pm 2.11(70-90)$ & $103 \pm 2.26(90-110)$ \\
\hline
\end{tabular}

Values are mean \pm standard error (S.E.).

\section{Discussion:}

In the present study it was found that the frequency of hypertension increases with increasing of age in all groups which are in accordance with the former studies of Roberts and Mauer (1977) in America and Mohsen et al. (1999) in Saudi Arabia. The results of our study reveled that the men value of serum cholesterol, triglyceride and LDL-cholesterol was significantly higher and significantly lower HDL-Cholesterol level was found in hypertensive patients than those of the control group. The findings of increased total cholesterol in patients with hypertension are slightly higher than the study of Shahadat et al. (1999) at home and consistent with the study at abroad (Adedeji and Onitiri1990, Assmann 1982 and Kristensen 1981).

The findings of raised triglyceride level are significantly higher that the study of Bangladesh by Shahadat et al. (1999) and are in good agreement with the prospective studies carried out in Stockholm (Carlson and Bottiger 1972), in Finland (Pelkonen 1977) and in Houston (Gotto et al. 1978) but differed with Framingham (Gordon and Gordon 1977) study where they observed that only post-menopausal females have hypertriglyceridemia. Serum HDL-cholesterol level in hypertensive patients was found to be lower than the findings of Shahadat et al. (1999) at home and of the past (Castilli et al. 1977, Wilson et al. 1980, Person et al.1979 and Miller et al.1977) but serum LDL-cholesterol level corroborated with the study of Shahadat et al. (1999) 
of Bangladesh, The Framingham Offspring Study (Wilson et al. 1980) and also with the co-operative phenotyping study (Castilli et al. 1977) in U S A, who demonstrated a positive correlation between the level of LDL-cholesterol and coronary risk. In our study, no significant difference of serum lipid profile between male and female hypertensive patients was found but total cholesterol, triglyceride and LDL- cholesterol were significantly higher in male than female controls whereas HDL-cholesterol was vice-versa.

Based on the results obtained from the present study, we concluded that serum cholesterol; triglyceride and LDL-cholesterol levels are positively correlated with hypertensive patients whereas HDL-cholesterol has no significant changes with hypertension. The higher level of serum TC, TG and LDL-cholesterol in the study population may be due to genetic factors and increased consumption of dietary animal fat, lack of physical exercise, metabolic disorders like diabetes Mellitus and hypothyroidism, severe stress, increased age, sex as well as alcohol and tobacco consumption may also be the contributory factors for this phenomenon.

\section{Acknowledgements}

The author wishes to thank Dr. Fakrul Islam, Department of Cardiology, Rajshahi Medical College, Rajshahi, Bangladesh for his valuable suggestion and laboratory help.

\section{References}

Adedeji $O$ O and Onitiri A C (1990) Lipids in Nigerian hypertensives. Afr. J. Med. Sci. 19: 281-284.

Allain C C, Poon I S, Chan C H G, Richmond W and Fu P C (1974) Enzymatic determination of serum total cholesterol. Clin. Chem. 20: 470-471.

Assmann G (1982) Lipid metabolism and atherosclerosis. Schattauer verlag , Stuttgart, Germany.

Bangladesh Health Services Report (1998) Cause of death and morbidity profile. Directorate General Health Services, Government of Bangladesh.

Burke G L, Sprafka J M, Folsom A R, Hahn I P, Luepker R V and Blackburn H (1991) Trends of serum cholesterol levels from 1980 to 1987. The Minnesota Heart Survey. N. Eng. Med. J. 342 (14): 941-946.

Carlson L A and Bottiger L E (1972) Ischemic heart disease in relation to fasting values of plasma triglycerides and cholesterol in Stockholm prospective study. Lancet. 1: 865-868.

Castilli W P, Doyle J T, Gordon T, Hames C J, Hjortland M C, Hullay S B, Kagan A and Zukel W K (1977) HDL-cholesterol and other lipid in coronary heart disease. The cooperative phenotyping study. Circulation 55 (5): 767-772.

Friedewald W T, Levy R I and Fredrickson D S (1972) Estimation of the concentration of LDL-cholesterol. Clin. Chem. 18 (6): 499-515.

Gordon T and Gordon M (1977) Enzymatic method to determine the serum HDL-cholesterol. Am. J. Med. 62: 707-708.

Gotto A M, Gorry G A and Thomson J R (1978) Relationship between plasma lipid concentration and coronary artery disease in 496 patients. Circulation 56 (5): 875-883.

Jacobs N J and VanDenmark P J (1960) Enzymatic determination of serum triglyceride.ch. Biochem. Biophys. 88: 250-255.

Kristensen B O (1981) Triglycerides and HDL-cholesterol in essential hypertension. Acta. Med. Scand. (suppl), 646: 31-42.

Lipid Research Clinics Program (1984). The lipid research clinics coronary primary prevention trial results-2. JAMA. 251: 365-374. 
Miller N E, Thelle D S, Finde O H and Mjos O D (1977) The Thromo Heart Study in HDL-cholesterol and coronary heart disease. A prospective case-control study. Lancet 1: 965-968.

Mohsen A F, El-Hazmi and Arjmand S Warsy (1999) Hypertension in Saudi Arabia. Saud. J. Kid. Dis. Transplant 10 (3): 365-371.

Pelkonen R, Nikkila E A, Koskinen S, Penttinen K and Sarna S (1977) Association of serum lipids and obesity with cardiovascular mortality. BMJ. 2: 1185-1187.

Person T A, Bulkley B H, Achuff S C and Gordis L (1979) Association of low levels of HDL-cholesterol and arteriografically defined coronary artery disease. Am. J. Epidemiol. 109: 285-291.

Shahadat H, Maliha R, Iqbal A and Suhrab A (1999) Study of serum lipid profile in essential hypertensive patients. Mym. Med. J. 8(1): 22-25.

WHO (1978) Classification of hypertension. Report of WHO Scientific Group, Technical Report Series, 657: 87-95.

Williams G H and Braunwald E (1987) Hypertensive vascular disease. In: Harrison's Principles of Internal Medicine. Prentice Hall.

Wilson P W, Garroson R J, Castilli W P, Feinleib M, McMamara P M and Kannel W B (1980) Prevalence of CHD in the Framingham Offsping study. Role of lipoprotein cholesterols. Am. J. Cardiol. 46: 649-654. 